\title{
Effect of water hyacinth compost on the morpho-physiological parameters of Soybean (Glycine max l.)
}

\author{
Ogbuehi $\mathrm{HC}^{*}$ and Ibe PK \\ Department of Crop science and Biotechnology, Faculty of Agriculture and Veterinary Medicine Imo State University, P.M.B \\ 2000, Owerri Imo State, Nigeria.
}

International Journal of Biological and Pharmaceutical Sciences Archive, 2021, 02(01), 084-095

Publication history: Received on 02 June 2021; revised on 30 July 2021; accepted on 02 August 2021

Article DOI: https://doi.org/10.53771/ijbpsa.2021.2.1.0058

\begin{abstract}
A pot experiment was conducted under rainfed condition to study the effect of water hyacinth compost on the morphophysiological parameters of soybean (Glycine max L.) at the Teaching and Research Farm of Faculty of Agriculture and Veterinary Medicine, Imo State University, Owerri. The treatments were control (T1) 100g (T2), 150g (T3) and 200g (T4) of water hyacinth compost and replicated four times. The treatments were arranged in Complete Randomized Design (CRD). The parameters measured were plant height, number of leaves, leaf area (cm2), leaf area index, relative growth rate (RGR), Net assimilation rate (NAR), shoot dry weight(g), yield and yield components (Number of pods, pods weight, 100 seed weight). The results obtained indicated that T3 significantly produced highest plant height (57.6cm) compare to control. While it was observed that T4 (200g) significantly produced the highest number of leaves (233.25), leaf area $(631.80 \mathrm{~cm} 2)$, shoot dry weight (15.445g), number of pods (129.75), pod weights (25.38g) seed weight (7.23g) and yield $(0.72 \mathrm{~kg} / \mathrm{ha})$ relative to control and other treatment levels. Root parameters were also significantly improved by the rates of water hyacinth application compared to control. It will be worthy to note that there was no nodulation perhaps that was why the yield was poor. The results showed that soybean growth can effectively be improved with incorporation of water hyacinth into soil.
\end{abstract}

Keywords:Water hyacinth; Soybean; Morpho-physiological parameters; Yield

\section{Introduction}

Organic manuring is becoming an important component of environmentally sound Sustainable agriculture. Residual nature of organic sources makes them more value based for the whole system compared to individual crops [1] Organic materials hold great promise as a source of multiple nutrients and ability to improve soil characteristics [2] Recently, the use of organic materials as fertilizers for crop production has received attention for sustainable crop productivity [3].

Eichhornia crassipes (Mart). Solms, commonly known as the water hyacinth family pontederiaceae and has a cosmopolitan distribution but are mostly found in warmer areas [4]. Water hyacinth is a free-floating aquatic weed which are considered nuisance around the world and very disturbing ecological processes [5.6]. Eichhornia crassipes have an environmental impact and socio-economic serious aquatic ecosystems from tropical and subtropical regions [7.8] . This plant has a rapid growth, large biomass, and tolerance for many metals / metalloids such as arsenic [9], cadmium [4], chromium [10], copper [11], iron [12], nickel [13], and zinc [14]. Eichhornia crassipes is also the plant to reduce and absorb toxic heavy metals and other pollutants from wastewater [15].

\footnotetext{
${ }^{*}$ Corresponding author: Ogbuehi HC

Department of Cropscience and Biotechnology, Faculty of Agriculture and Veterinary Medicine Imo State University, P.M.B 2000,Owerri Imo State, Nigeria. 
Water hyacinth can be processed into compost, animal feed and the production of biogas $[16,17.18]$.

Compost and poultry manure significantly increased growth fresh and dry weight of shoot and root and yield of tomato compared to control [19].Past research has shown that the use of water hyacinth as a source of organic material capable of improving the physical structure of the soil, increasing the availability of nutrients, vegetative growth and the production of sweet corn [20].The study of water hyacinth as bio fertilizer revealed that the incorporation of water hyacinth into soil crop system increased the performance yield of the crop plant Coriandrum sativum [21].

[22] also highlighted that using composted water hyacinth material could serve as quality manure for improving soil fertility conditions and thus crop yields on the whole.

Soybean is widely cultivated in the subtropical ecological zone of Nigeria and throughout the world. Soybeans grows best on soils of medium to high fertility and with a favourable soil PH of 6.0-6-5. Maximum yields are possible only when producers meet plant nutritional requirements and other basic production factors [23].

Soybeans can be grown throughout the year in the tropics and sub-tropics, if water is available. Soybean requires 400 to $500 \mathrm{~mm}$ in a season for a good crop. High moisture requirement is critical at the time of germination, flowering and pod forming stage [24].

However dry weather is necessary for ripening soybeans can tolerate brief water logging in the rainy season [25].

The major objective study is to investigate the effect of different rate of Water Hyacinths compost used as soil amendment on the growth and yield of Soybean.

\section{Material and methods}

\subsection{Study Location}

The experiment was conducted at the Teaching and research Farm of Faculty of Agriculture and Veterinary Medicine, Imo State University, Owerri. Owerri lies between latitudes $5^{\circ} 20^{\prime} \mathrm{N}$ and $6^{\circ} 55^{\prime} \mathrm{E}$, and longitudes $6^{\circ} 35^{\prime} \mathrm{E}$ and $7^{\circ} 08^{\prime} \mathrm{E}$ on elevation of $71 \mathrm{~m}$ above the sea level, within the South East Rain Forest Agricultural Zone of Nigeria. The area as reported by [26] maintains an average annual rainfall of $2,500 \mathrm{~mm}$, temperature $27^{\circ} \mathrm{C}$ and Relative humidity of $85 \%$;

\subsection{Experimental Materials}

Seeds of soybean were procured from National Agricultural Seeds Council (NASC) Federal Ministry of Agriculture and Rural Development. Seed variety: TGX 1448 - 2E.

\subsection{Water Hyacinth as Treatment}

Table 1 Chemical Composition of Water Hyacinth Compost Manure

\begin{tabular}{|l|c|}
\hline \multicolumn{1}{|c|}{ Nutrient } & Value \\
\hline Iron & $4.0 \mathrm{mg} / \mathrm{kg}$ \\
\hline Phosphorus & $2.6 \mathrm{mg} / \mathrm{kg}$ \\
\hline Potassium & $2600 \mathrm{mg} / \mathrm{kg}$ \\
\hline Calcium & $0.15 \mathrm{mg} / \mathrm{kg}$ \\
\hline Zinc & $112.8 \mathrm{mg} / \mathrm{kg}$ \\
\hline Nitrogen & $0.1 \%$ \\
\hline Carbon & $26.1 \%$ \\
\hline Carbon /Nitrogen ration & 26.1 \\
\hline
\end{tabular}


Large quantity of water hyacinth was collected from Shagaya Farm Limited, Rumuokwurusi, Port Harcourt, Rivers State. The roots were detached and water hyacinth was left to completely dry under the sun for 60 days and it was grounded into large particle size using an Industrial Grounding Machine.

Sample of the large particle size of water hyacinth were taken to the laboratory for analysis of its chemical composition.

\subsection{Experimental Design and Layout}

The experiment was laid out in Randomized Complete Randomized Design (CRD) with four replicates. (0g/plant, $100 \mathrm{~g} /$ plant, $150 \mathrm{~g} / \mathrm{plant}$ and $200 \mathrm{~g} / \mathrm{plant}$ ) formed the treatment and it was replicated four times.

\subsection{Planting and Agronomic Operations}

Pots were purchased and filled with soil, soybean seeds were planted at a depth of $2-3 \mathrm{~cm}$ in pots with two seeds per hole, and pots were placed at a distance of $80 \times 80 \mathrm{~cm}$ apart. Thinning was done at 14 days after planting to reduce the plant stand to one per hole. Weeding was done by hand picking throughout the period of research to keep the pots weed free.

\subsection{Data Collection}

The following parameters were collected:

\subsubsection{Plant Height}

This is the distance from the ground level of the plant to the Apex of the plant. It was measured using ruler (graduated in centimeter).

\subsubsection{Leaf Area per Plant $\left(\mathrm{cm}^{2}\right)$}

This was calculated using the

formula: $6.532+2.045\left(\mathrm{Li}_{\mathrm{i}}\right)$ were $\mathrm{Li}_{\mathrm{i}}=$ maximum lengths of terminal leaflet of the leaf.

$\mathrm{W}_{\mathrm{i}}=$ maximum width of terminal leaflet of the leaf.

\subsubsection{Leaf Area Index Per Plant}

This was obtained by a simple formular, leaf area index per plant $=\frac{\text { Leaf Area per plant }}{\text { Area covered by the leaf }}$

\subsubsection{Relative Growth Rate $\left(g g^{-1} w^{-1}\right)$}

Is the growth rate relative to the size of the population. It is also called the exponential growth rate or the continuous growth rate. It was calculated using the formular blow.

$$
\text { Relative Growth Rate }=\frac{\log \mathrm{W} 2-\log \mathrm{W} 1}{\mathrm{~T} 2-\mathrm{T} 1}
$$

$\mathrm{W}_{1}=$ initial weight

$\mathrm{W}_{2}=$ subsequent weight

$\mathrm{T}_{2}=$ subsequent time

$\mathrm{T}_{1}=$ initial time

\subsubsection{Net Assimilation Rate (NAR) $\left(\mathrm{gcm}^{2} \mathrm{wk}^{-1}\right)$}

Net AssimilationRate was calculated using the formular below

$$
\mathrm{NAR}=\frac{(\mathrm{L} 2-\mathrm{L} 1)}{\mathrm{T} 2-\mathrm{T} 1} \times \frac{\mathrm{W} 2-\mathrm{W} 1}{\mathrm{~L} 2-\mathrm{L} 1}
$$

Where,

$\mathrm{W}_{1}$ - initial weight 
$\mathrm{W}_{2}$ - subsequent weight

$\mathrm{L}_{1}$ - initial leaf area

$\mathrm{L}_{2}$ - subsequent leaf area

$\mathrm{T}_{1}$ - initial time

$\mathrm{T}_{2}$ - subsequent time

\subsubsection{Shoot Dry Weight}

It was obtained by drying the shoot in a Lasany digital hot air oven at $80^{\circ} \mathrm{C}$ for 24 hours and was weighed using a Kern, EWJ 300-3 analytical weighing balance.

\subsubsection{Root Length}

$\mathrm{t}$ was measured using ruler (graduated in centimetre).

\subsubsection{Number of Root}

This was done by visual counting of the roots using the hand lens.

\subsubsection{Root Dry Weight}

It was obtained by drying the root in a Lasany digital hot air oven $80^{\circ} \mathrm{C}$ for 24 hours and was weighed using a EWJ 3003 analytical weighing balance.

\subsubsection{Number of pods}

This was obtained by visual counting of pods per plot.

\subsubsection{0 seed weight}

This was calculated using 100 dried seeds of soybean.

\subsubsection{Yield}

This was calculated with the formula;

$$
\text { Yeild }=\frac{\text { Seed weight }(\mathrm{Kg})}{\text { Land area }(\mathrm{m} 2)} \times 10,000
$$

\subsection{Statistical Analysis}

Data obtained were subjected to statistical analysis using Analysis of Variance (ANOVA) to determine if the treatments have any significant effect on parameters measured. All data were analyzed according to One-Way ANOVA using SPSS software version 20.0 .

\section{Results and discussion}

\subsection{Effect of Treatment on Plant Height (cm) of Soybean}

The data analysis on plant height is presented in Table 1 . The result showed that application of water hyacinth compost significantly improved the plant height. At 2 and 4 weeks After planting(WAP), T3 recorded the highest plant heights $(11.150 \mathrm{~cm}$ and $23.150 \mathrm{~cm}$ respectively) which was not significantly different $(\mathrm{P}<0.05)$ the lowest plant heights $\left(10.050 \mathrm{~cm}\right.$ and $18.050 \mathrm{~cm}$ respectively) obtained from $T_{2}$ and $T_{1}$. Among the treated plots $T_{2}$, recorded the lowest plant height $(19.400 \mathrm{~cm})$, this was followed by $\mathrm{T}_{4}$ with plant height of $21.325 \mathrm{~cm}$ but not significant to each other. At 6,8 and 10WAP, $T_{3}$ recorded the highest plant heights $(44.475 \mathrm{~cm}, 55.475 \mathrm{~cm}$ and $57.600 \mathrm{~cm}$ respectively) which was significantly different $(\mathrm{P}<0.05)$ from the lowest plant heights $(30.250 \mathrm{~cm}, 38.550 \mathrm{~cm}$ and $40.150 \mathrm{~cm}$ respectively) obtained from control as shown in Table 1. Also, it was observed that among the treated plots $\mathrm{T}_{2}$ recorded the lowest plants heights as shown in Table 1, this was followed by $\mathrm{T}_{4}$. 
Table 1 Effect of Treatments on Plant Height $(\mathrm{cm})$ of Soybean

\begin{tabular}{|c|c|c|c|c|c|}
\hline Treatments & 2WAP & 4WAP & 6WAP & 8WAP & 10WAP \\
\hline $\mathrm{T}_{1}-$ Control & $11.50^{\mathrm{a}}$ & $18.050^{\mathrm{a}}$ & $30.250^{\mathrm{b}}$ & $38.550^{\mathrm{b}}$ & $40.150^{\mathrm{b}}$ \\
\hline $\mathrm{T}_{2}$ & $10.050^{\mathrm{a}}$ & $19.400^{\mathrm{a}}$ & $35.825^{\mathrm{ab}}$ & $40.925^{\mathrm{b}}$ & $45.125^{\mathrm{ab}}$ \\
\hline $\mathrm{T}_{3}$ & $11.150^{\mathrm{a}}$ & $23.150^{\mathrm{a}}$ & $44.475^{\mathrm{a}}$ & $55.475^{\mathrm{a}}$ & $57.600^{\mathrm{a}}$ \\
\hline $\mathrm{T}_{4}$ & $10.225^{\mathrm{a}}$ & $21.325^{\mathrm{a}}$ & $35.250^{\mathrm{ab}}$ & $47.025^{\mathrm{ab}}$ & $53.750^{\mathrm{a}}$ \\
\hline \multicolumn{5}{c}{ Mean on the same column with same letter(s) are not significantly different $(\mathrm{P}<0.05)$} \\
\hline
\end{tabular}

\subsection{Effect of Treatments on Number of Leaves of Soybean}

The result on the number of leaves showed that application of water hyacinth significantly increased the number of leaves (Table 2).At 2 WAP, $\mathrm{T}_{2}$ and $\mathrm{T}_{3}$ had the same number of laves (8) which was not significantly different $(\mathrm{P}<0.05)$ from the number of leaves (7.75) obtained both in control and in $\mathrm{T}_{4}$ treated plots. However, at $46 \mathrm{WAP}, \mathrm{T}_{3}$ obtained the highest quantity of leaves ( 43.5 and 112 , respectively) which was significantly different $(\mathrm{P}<0.05)$ from the lowest number of leaves (20 and 38) recorded from control. Whereas among the treated plots, $\mathrm{T}_{2}$ had minimum number of leaves (33.750 and 89.75), followed by $\mathrm{T}_{4}$ with number of leaves ( 40 and 90.5 ) higher than $\mathrm{T}_{2}$. Also, it was observed that at 8 and 10WAP, $\mathrm{T}_{4}$ had mean maximum number of leaves (158.25 and 233.25) which was significantly different $(\mathrm{P}<0.05)$ from the minimum number's leaves $(80.25$ and 133.75 respectively) obtained from control plots. Moreover, the result in Table 2 showed that among the treated plots $\mathrm{T}_{2}$ had the lowest number of leaves when compared to $\mathrm{T}_{3}$ and $\mathrm{T}_{4}$ as shown in Table 2.

Table 2 Effect of Treatments on Number of Leaves of Soybean

\begin{tabular}{|c|c|c|c|c|c|}
\hline Treatments & 2WAP & 4WAP & 6WAP & 8WAP & 10WAP $^{\text {(WW }}$ \\
\hline $\mathrm{T}_{1}-$ Control & $7.750^{\mathrm{a}}$ & $20.000^{\mathrm{b}}$ & $38.00^{\mathrm{b}}$ & $80.75^{\mathrm{b}}$ & $133.75^{\mathrm{b}}$ \\
\hline $\mathrm{T}_{2}$ & $8.000^{\mathrm{a}}$ & $33.750^{\mathrm{ab}}$ & $89.75^{\mathrm{a}}$ & $144.75^{\mathrm{ab}}$ & $214.75^{\mathrm{a}}$ \\
\hline $\mathrm{T}_{3}$ & $8.000^{\mathrm{a}}$ & $43.500^{\mathrm{a}}$ & $112.00^{\mathrm{a}}$ & $157.25^{\mathrm{a}}$ & $228.75^{\mathrm{a}}$ \\
\hline $\mathrm{T}_{4}$ & $7.750^{\mathrm{a}}$ & $40.000^{\mathrm{a}}$ & $90.50^{\mathrm{a}}$ & $158.25^{\mathrm{a}}$ & $233.25^{\mathrm{a}}$ \\
\hline \multicolumn{7}{|c}{} \\
\hline
\end{tabular}

\subsection{Effect of Treatment on Leaf Area $\left(\mathrm{cm}^{2}\right)$ of Soybean}

The data from Table 3 indicates that there was a significant different $(\mathrm{P}<0.05)$ among the treatments at 2 and 4 WAP, where $\mathrm{T}_{4}$, at $2 \mathrm{WAP}$ recorded the maximum leaf area $\left(237.60 \mathrm{~cm}^{2}\right)$ which was not significantly different $(\mathrm{P}<0.05)$ from the minimum leaf area $\left(142.79 \mathrm{~cm}^{2}\right)$ obtained in $\mathrm{T}_{2}$ treated plots. Whereas at $4 \mathrm{WAP}, \mathrm{T}_{3}$ had the highest leaf area $\left(372.85 \mathrm{~cm}^{2}\right)$ which was not significantly different $(\mathrm{P}<0.05)$ from the lowest $\left(192.88 \mathrm{~cm}^{2}\right)$ obtained from control. However, at 6WAP $\mathrm{T}_{2}$ had significantly higher leaf area $\left(557.83 \mathrm{~cm}^{2}\right)$ than the lowest $\left(322.67 \mathrm{~cm}^{2}\right)$ obtained in control. The result also showed that at 8 and 10WAP, $\mathrm{T}_{4}$ recorded the maximum leaf areas $\left(631.80 \mathrm{~cm}^{2}\right.$ and $\left.614.0 \mathrm{~cm}^{2}\right)$ which was significantly different $(\mathrm{P}<0.05)$ from the minimum leaf area $\left(31.66 \mathrm{~cm}^{2}\right.$ and $329.3 \mathrm{~cm}^{2}$ respectively) obtained in control plots.

Table 3 Effect of Treatments on Leaf Area (cm2) of Soybean

\begin{tabular}{|c|c|c|c|c|c|}
\hline Treatments & 2WAP & 4WAP & 6WAP & 8WAP & 10WAP \\
\hline $\mathrm{T}_{1}$ - Control & $192.60^{a}$ & $192.88^{a}$ & $322.67^{b}$ & $313.66^{b}$ & $329.3^{b}$ \\
\hline $\mathrm{T}_{2}$ & $142.79^{a}$ & $298.69^{a}$ & $557.83^{a}$ & $535.57^{a}$ & $466.8^{\mathrm{ab}}$ \\
\hline $\mathrm{T}_{3}$ & $190.54^{\mathrm{a}}$ & $372.85^{a}$ & $508.79 a$ & $493.16^{a}$ & $559.3^{\mathrm{ab}}$ \\
\hline $\mathrm{T}_{4}$ & $237.60^{a}$ & $315.70^{\mathrm{a}}$ & $529.67^{a}$ & $631.80^{a}$ & $614.0^{\mathrm{a}}$ \\
\hline
\end{tabular}




\subsection{Effect of Treatments on Leaf Area Index}

Soybean plant was not significantly different $(\mathrm{P}<0.05)$ in the leaf area index at 2WAP and 4WAP with $\mathrm{T}_{3}$ having the highest mean leaf area index of 0.586 and 0.376 respectively while the lowest mean was obtained from $\mathrm{T}_{1}(0.430$ and 0.358 ) respectively, comparing between the treated plots $\mathrm{T}_{4}$ had the lowest mean in the leaf area index 0.519 and 0.296 in 2WAP \& 4WAP respectively as shown in Table 4. A mean leaf area index of 0.508 was recorded as the highest at $6 \mathrm{WAP}$ obtained from $\mathrm{T}_{2}$ which was not significantly different $(\mathrm{P}<0.05)$ from $\mathrm{T}_{4}$ that had a mean leaf area index of 0.362 , but $\mathrm{T}_{2}$ was significantly different $(\mathrm{P}<0.05)$ from $\mathrm{T}_{1}$ and $\mathrm{T}_{3}$ that had mean of leaf area index 0.312 and 0.269 respectively $\mathrm{T}_{3}$ had a significantly low leaf area index as compared to $\mathrm{T}_{2}$ within the treated plots at $6 \mathrm{WAP}$. But at 8WAP and $10 \mathrm{WAP} \mathrm{T}_{2}$ $(0.357$ and 0.371$)$ respectively had the highest mean leaf area index and was not significantly different $(\mathrm{P}<0.05)$ from $\mathrm{T}_{1}(0.184$ and 0.247$)$ and $\mathrm{T}_{4}(0.267$ and 0.206$)$ at $8 \mathrm{WAP}$ and $10 \mathrm{WAP}$ respectively as shown in Table $4, \mathrm{~T}_{3}(0.143$ and 0.150 ) had the lowest mean leaf area index at 8WAP and 10WAP respectively.

Table 4 Effect of Treatments on Leaf Area Index of Soybean

\begin{tabular}{|c|c|c|c|c|c|}
\hline Treatments & 2WAP & 4WAP & 6WAP & 8WAP & 10WAP \\
\hline $\mathrm{T}_{1}-$ Control & $0.430^{\mathrm{a}}$ & $0.358^{\mathrm{a}}$ & $0.312^{\mathrm{b}}$ & $0.184^{\mathrm{ab}}$ & $0.247^{\mathrm{ab}}$ \\
\hline $\mathrm{T}_{2}$ & $0.546^{\mathrm{a}}$ & $0.323^{\mathrm{a}}$ & $0.508^{\mathrm{a}}$ & $0.357^{\mathrm{a}}$ & $0.371^{\mathrm{a}}$ \\
\hline $\mathrm{T}_{3}$ & $0.586^{\mathrm{a}}$ & $0.376^{\mathrm{a}}$ & $0.269^{\mathrm{b}}$ & $0.143^{\mathrm{b}}$ & $0.150^{\mathrm{b}}$ \\
\hline $\mathrm{T}_{4}$ & $0.519^{\mathrm{a}}$ & $0.296^{\mathrm{a}}$ & $0.362^{\mathrm{ab}}$ & $0.267^{\mathrm{ab}}$ & $0.206^{\mathrm{ab}}$ \\
\hline \multicolumn{7}{|c}{ Mean on the some column with same letter(s) are not significantly different $(\mathrm{P}<0.05)$}
\end{tabular}

\subsection{Effect of Treatment on the Relative Growth Rate(RGR) of Soybean}

The application of water hyacinth compost improved the growth rate of the Soybean plant. The data analysis shown in Table 5 indicated that at $2 \mathrm{WAP}, \mathrm{T}_{4}$ recorded the highest relative growth rate $\left(0.074 \mathrm{gg}^{-1} \mathrm{wk}^{-1}\right)$ which was significantly different $(\mathrm{P}<0.05)$ from the lowest relative growth rate $\left(0.037 \mathrm{gg}^{-1} \mathrm{wk}^{-1}\right)$ obtained from $\mathrm{T}_{2}$. At $4 \mathrm{WAP}$ and $6 \mathrm{WAP} \mathrm{T}_{3}$ recorded the highest relative growth of $0.419 \mathrm{gg}^{-1} \mathrm{wk}^{-1}$ and $0.345 \mathrm{gg}^{-1} \mathrm{wk}^{-1}$ respectively which was significantly different $(\mathrm{P}<0.05)$ from the lowest relative growth rate $\left(0.269 \mathrm{gg}^{-1} \mathrm{wk}^{-1}\right.$ and $\left.0.078 \mathrm{gg}^{-1} \mathrm{wk}^{-1}\right)$ respectively obtained from $\mathrm{T}_{2}$ as shown in the Table 10 , whereas at $8 \mathrm{WAP}, \mathrm{T}_{1}$ recorded the maximum relative growth rate of the Soybean $\left(0.604 \mathrm{gg}^{-1} \mathrm{Wk}^{-}\right.$ 1) which was significantly different $(\mathrm{P}<0.05)$ from the minimum relative growth rate obtained from $\mathrm{T}_{3}\left(0.210 \mathrm{gg}^{-1} \mathrm{Wk}^{-1}\right)$. Whereas at 10WAP, $\mathrm{T}_{3}$ had the highest relative growth rate of $0.127 \mathrm{gg}^{-1} \mathrm{wk}^{-1}$ which was significantly different $(\mathrm{P}<0.05)$ from the minimum relative growth rate obtained in $\mathrm{T}_{2}$.

Table 5 Effect of Treatments on the Relative Growth Rate (gg-1wk-1)

\begin{tabular}{|c|c|c|c|c|c|}
\hline Treatments & 2WAP & 4WAP & 6WAP & 8WAP & 10WAP \\
\hline $\mathrm{T}_{1}-$ Control & $0.083^{\mathrm{a}}$ & $0.285^{\mathrm{b}}$ & $0.117^{\mathrm{b}}$ & $0.604^{\mathrm{a}}$ & $0.094^{\mathrm{bc}}$ \\
\hline $\mathrm{T}_{2}$ & $0.037^{\mathrm{b}}$ & $0.269^{\mathrm{b}}$ & $0.078^{\mathrm{b}}$ & $0.592^{\mathrm{a}}$ & $0.077^{\mathrm{c}}$ \\
\hline $\mathrm{T}_{3}$ & $0.067^{\mathrm{ab}}$ & $0.419^{\mathrm{a}}$ & $0.345^{\mathrm{a}}$ & $0.210^{\mathrm{c}}$ & $0.127^{\mathrm{a}}$ \\
\hline $\mathrm{T}_{4}$ & $0.074^{\mathrm{a}}$ & $0.385^{\mathrm{a}}$ & $0.252^{\mathrm{a}}$ & $0.375^{\mathrm{b}}$ & $0.115^{\mathrm{ab}}$ \\
\hline
\end{tabular}

\subsection{Effect of Treatment on Net Assimilation Rate $\left(\mathrm{gcm}^{2} \mathbf{w k}^{-1}\right)$}

The various treatments had a significant effect on the net assimilation rate(Table.6).At 2WAP the result obtained showed that control $\mathrm{T}_{1}\left(0.004 \mathrm{gcm}^{2} \mathrm{wk}^{-1}\right)$ had the lowest mean net assimilation while $\mathrm{T}_{4}\left(0.0015 \mathrm{gcm}^{2} \mathrm{wk}^{-1}\right) \mathrm{had} \mathrm{the}$ highest mean net assimilation rate. But all treatments were not significantly different $(\mathrm{P}<0.05)$. But comparison of the treated plots, treatments $\mathrm{T}_{3}\left(0.009 \mathrm{gcm}^{2} \mathrm{wk}^{-1}\right)$ had the lowest net assimilation. At 4WAP, 6WAP, 8WAP \& 10WAP, T had highest mean assimilation rate of $0.0005 \mathrm{gcm}^{2} \mathrm{wk}^{-1}, 0.0015 \mathrm{gcm}^{2} \mathrm{wk}^{-1}, 0.0078 \mathrm{gcm}^{2} \mathrm{wk}^{-1}$ and $0.0029 \mathrm{gcm}^{2} \mathrm{wk}^{-1}$ and plants under the control experiment had the lowest mean net assimilation rate of $0.0002 \mathrm{gcm}^{2} \mathrm{wk}^{-1}, 0.0001 \mathrm{gcm}^{2} \mathrm{wk}^{-1}, 0.002$ $\mathrm{gcm}^{2} \mathrm{wk}^{-1} \& 0.0013 \mathrm{gcm}^{2} \mathrm{wk}^{-1}$ respectively as shown in Table 6 in the treated plots, $\mathrm{T}_{2}$ had the lowest mean net assimilation rate at 4WAP, 6WAP and $10 \mathrm{WAP}$ as they measured $0.0003 \mathrm{gcm}^{2} \mathrm{wk}^{-1}, 0.0001 \mathrm{gcm}^{2} \mathrm{wk}^{-1} \mathrm{and}_{0.0018 \mathrm{gcm}^{2} \mathrm{wk}}$ ${ }^{1}$ respectively but was higher than $\mathrm{T}_{4}$ at $8 \mathrm{WAP}$ at it measured $0.0036 \mathrm{gcm}^{2} \mathrm{wk}^{-1}$ while $\mathrm{T}_{4}$ measured $0.0029 \mathrm{gcm}^{2} \mathrm{wk}^{-1}$, 
they were not significantly different $(\mathrm{P}<0.05)$ also at 4WAP and $10 \mathrm{WAP}$ but were significantly different $(\mathrm{P}<0.05)$ at $6 \mathrm{WAP}$ as $\mathrm{T}_{4}$ measured $0.0007 \mathrm{gcm}^{2} \mathrm{wk}^{-1}$ mean net assimilation rate.

Table 6 Effect of Treatments on Net Assimilation Rate (gcm2wk-1)

\begin{tabular}{|c|c|c|c|c|c|}
\hline Treatments & 2WAP & 4WAP & 6WAP & 8WAP & 10WAP \\
\hline $\mathrm{T}_{1}-$ Control & $0.0004^{\mathrm{a}}$ & $0.0002^{\mathrm{b}}$ & $0.0001^{\mathrm{c}}$ & $0.0022^{\mathrm{a}}$ & $0.0013^{\mathrm{b}}$ \\
\hline $\mathrm{T}_{2}$ & $0.0010^{\mathrm{a}}$ & $0.0003^{\mathrm{ab}}$ & $0.0001^{\mathrm{c}}$ & $0.0036^{\mathrm{a}}$ & $0.0018^{\mathrm{b}}$ \\
\hline $\mathrm{T}_{3}$ & $0.0009^{\mathrm{a}}$ & $0.0005^{\mathrm{a}}$ & $0.0015^{\mathrm{a}}$ & $0.0078^{\mathrm{a}}$ & $0.0029^{\mathrm{a}}$ \\
\hline $\mathrm{T}_{4}$ & $0.0015^{\mathrm{a}}$ & $0.0004^{\mathrm{a}}$ & $0.0007^{\mathrm{b}}$ & $0.0029^{\mathrm{a}}$ & $0.0022^{\mathrm{ab}}$ \\
\hline \multicolumn{7}{|c}{ Mean on the same column with same letter(s) are not significantly different $(\mathrm{P}<0.05)$} \\
\hline
\end{tabular}

\subsection{Effect of Treatments on Shoot Dry Weight(g)}

The result in Table 7 showed that the application of water hyacinth significantly increased the shoot. At 2 WAP there was no significant different $(\mathrm{P}<0.05)$ with $\mathrm{T}_{2}(0.140 \mathrm{~g})$ having the highest shoot dry weight and $\mathrm{T}_{1}(0.073 \mathrm{~g})$ having the lowest shoot dry weight. But comparison made within the treated plots $\mathrm{T}_{4}(0.088 \mathrm{~g})$ had the lowest shoot dry weight followed by $\mathrm{T}_{3}(0.103 \mathrm{~g})$. At $4 \mathrm{WAP} \mathrm{T}_{3}(0.672 \mathrm{~g})$ had the highest shoot dry weight and was not significantly different $(\mathrm{P}<0.05)$ from $\mathrm{T}_{2}(0.466 \mathrm{~g})$ and $\mathrm{T}_{4}(0.541 \mathrm{~g})$ but was significantly different $(\mathrm{P}<0.05)$ from $\mathrm{T}_{1}(0.270 \mathrm{~g})$ that had the lowest mean shoot dry weight. Significant difference $(\mathrm{P}<0.05)$ was recorded at $6 \mathrm{WAP}$ in $\mathrm{T}_{1}(0.160 \mathrm{~g}), \mathrm{T}_{3}(3.412 \mathrm{~g})$ and $\mathrm{T}_{4}$ $(1.631 \mathrm{~g})$ but having $\mathrm{T}_{2}(0.640 \mathrm{~g})$ not significantly different $(\mathrm{P}<0.05)$ from $\mathrm{T}_{1}$ and $\mathrm{T}_{4} . \mathrm{T}_{1}$ had the lowest shoot dry weight, followed by $\mathrm{T}_{2}$, then $\mathrm{T}_{4}$ but $\mathrm{T}_{3}$ had the highest shoot dry weight.

The result in Table 7, showed that the application of water hyacinth significantly increased the shoot dry weight, at the 8WAP and 10WAP with $\mathrm{T}_{2}$ (9.448g and 13.444g) $\mathrm{T}_{3}(8.538 \mathrm{~g}$ and $15.270 \mathrm{~g}) \mathrm{T}_{4}(9.048 \mathrm{~g}$ and 15.445g), the control recorded the lowest mean shoot dry weight of $3.35 \mathrm{~g}$ and $5.133 \mathrm{~g}$ respectively.

Table 7 Effect of Treatments on Shoot Dry Weight (g) of Soybean

\begin{tabular}{|c|c|c|c|c|c|}
\hline Treatments & 2WAP & 4WAP & 6WAP & 8WAP & 10WAP \\
\hline $\mathrm{T}_{1}-$ Control & $0.073^{\mathrm{a}}$ & $0.270^{\mathrm{b}}$ & $0.150^{\mathrm{c}}$ & $3.350^{\mathrm{b}}$ & $5.133^{\mathrm{b}}$ \\
\hline $\mathrm{T}_{2}$ & $0.140^{\mathrm{a}}$ & $0.466^{\mathrm{ab}}$ & $0.640^{\mathrm{bc}}$ & $9.448^{\mathrm{a}}$ & $13.444^{\mathrm{a}}$ \\
\hline $\mathrm{T}_{3}$ & $0.103^{\mathrm{a}}$ & $0.672^{\mathrm{a}}$ & $3.412^{\mathrm{a}}$ & $8.538^{\mathrm{a}}$ & $15.270^{\mathrm{a}}$ \\
\hline $\mathrm{T}_{4}$ & $0.088^{\mathrm{a}}$ & $0.541^{\mathrm{a}}$ & $1.631^{\mathrm{b}}$ & $9.048^{\mathrm{a}}$ & $15.445^{\mathrm{a}}$ \\
\hline
\end{tabular}

Mean on the same column with same letter(s) are not significantly different $(\mathrm{P}<0.05)$

\subsection{Effect of Treatments on Root Length $(\mathrm{cm})$ of Soybean}

The result in Table 8, showed that the application of water hyacinth significantly increased root length according to the different levels of treatments, At $2 \mathrm{WAP}$ and 4WAP there was no significant difference $(\mathrm{P}<0.05)$ except for $\mathrm{T}_{4}$ with lowest mean root length of $2.960 \mathrm{~cm}$ at $2 \mathrm{WAP}$ which made it significantly different $(\mathrm{P}<0.05)$ from the other treatments at $2 \mathrm{WAP}$, also $\mathrm{T}_{4}(8.958 \mathrm{~cm})$ had the lowest mean root length at 4 WAP but was not significantly different from $\mathrm{T}_{1}, \mathrm{~T}_{2}, \mathrm{~T}_{3}$ which had $11.075 \mathrm{~cm}, 11.320 \mathrm{~cm}$ and $11.935 \mathrm{~cm}$ respectively.

Table 8 Effect of Treatments on Root Length $(\mathrm{cm})$ of Soybean

\begin{tabular}{|l|l|l|l|l|l|}
\hline Treatments & 2WAP & 4WAP & 6WAP & 8WAP & 10WAP \\
\hline $\mathrm{T}_{1}-$ Control & $7.543^{\mathrm{a}}$ & $11.075^{\mathrm{a}}$ & $11.773^{\mathrm{c}}$ & $35.113^{\mathrm{b}}$ & $48.600^{\mathrm{a}}$ \\
\hline $\mathrm{T}_{2}$ & $6.380^{\mathrm{a}}$ & $11.320^{\mathrm{a}}$ & $20.010^{\mathrm{a}}$ & $38.210^{\mathrm{b}}$ & $52.625^{\mathrm{a}}$ \\
\hline $\mathrm{T}_{3}$ & $6.138^{\mathrm{a}}$ & $11.935^{\mathrm{a}}$ & $15.675^{\mathrm{b}}$ & $56.018^{\mathrm{a}}$ & $57.875^{\mathrm{a}}$ \\
\hline $\mathrm{T}_{4}$ & $2.960^{\mathrm{b}}$ & $8.958^{\mathrm{a}}$ & $18.100^{\mathrm{ab}}$ & $44.835^{\mathrm{ab}}$ & $57.300^{\mathrm{a}}$ \\
\hline \multicolumn{7}{|c|}{ Mean on the same column with same letter(s) are not significantly different $(\mathrm{P}<0.05)$}
\end{tabular}


At 6 WAP, $\mathrm{T}_{2}$ had the highest root length with data obtained as $20.010 \mathrm{~cm}$ which was significantly different $(\mathrm{P}<0.05)$ from $\mathrm{T}_{1}$ that had the lowest data obtained as $11.773 \mathrm{~cm}$. Among the treated plots $\mathrm{T}_{3}$ was the lowest with data obtained as $15.675 \mathrm{~cm}$.

\subsection{Effect of Treatments on the number of roots of Soybean}

Results of analysis of variance showed significant influence of treatments on the number of roots (Table9). At 2WAP, the lowest number of roots (31.50) was observed from $\mathrm{T}_{4}$ which was followed by $\mathrm{T}_{3}$ with mean number of roots (39.00) as shown in Table 9, but were not significantly different $(\mathrm{P}<0.05)$ from each other but were significantly different $(\mathrm{P}<0.05)$ from $\mathrm{T}_{2}(17.50)$ with highest mean number of roots $(77.5)$ followed by control with mean number of 59.50 . In the Table 9, 4WAP recorded $\mathrm{T}_{4}(82.50)$ as the mean highest number of roots which was significantly different $(\mathrm{P}<0.05)$ from $\mathrm{T}_{1}$ (53.75), $\mathrm{T}_{2}$ (58.50) and $\mathrm{T}_{3}$ (45.50) observing that $\mathrm{T}_{3}$ had the lowest mean number of roots. Among the treated plots in 6WAP $\mathrm{T}_{4}(117.25)$ had the highest number of roots while $\mathrm{T}_{2}$ (41.25) had the lowest followed by $\mathrm{T}_{3}$ (52.25). High number of roots was recorded in 8WAP and 10WAP with $\mathrm{T}_{4}$ having the highest number of roots 3982.3 and 6311.5 respectively which was significantly different from the control which had 1039.8 and 1995.5 respectively (Table 9). The Table 9 also shows that $\mathrm{T}_{4}$ had the highest number of roots in 4WAP, 6WAP 8WAP and 10WAP except in 2WAP were it had the lowest mean number of roots.

Table 9 Effect of Treatments on Number of Roots of Soybean

\begin{tabular}{|c|c|c|c|c|c|}
\hline Treatments & 2WAP & 4WAP & 6WAP & 8WAP & 10WAP \\
\hline $\mathrm{T}_{1}-$ Control & $59.50^{\mathrm{ab}}$ & $53.75^{b}$ & $80.00^{\mathrm{b}}$ & $1039.8^{b}$ & $1995.5^{b}$ \\
\hline $\mathrm{T}_{2}$ & $77.50^{\mathrm{a}}$ & $58.50^{\mathrm{b}}$ & $41.25^{c}$ & $1865.5^{b}$ & $2875.8^{b}$ \\
\hline $\mathrm{T}_{3}$ & $39.00^{\mathrm{b}}$ & $45.50^{\mathrm{b}}$ & $52.25^{b c}$ & $2016.8^{b}$ & $5052.3^{\mathrm{a}}$ \\
\hline $\mathrm{T}_{4}$ & $31.50^{\mathrm{b}}$ & $82.50^{\mathrm{a}}$ & $117.25^{\mathrm{a}}$ & $3982.3^{a}$ & $6311.5^{a}$ \\
\hline
\end{tabular}

\subsection{Effect of Treatments on the Root Dry Weight(g) of Soyabean}

The root dry weight of Soybean grown under the different soil application of water hyacinth treatment was significantly different $(\mathrm{P}<0.05)$ Table 10. Roots from $\mathrm{T}_{1}, \mathrm{~T}_{3}$ and $\mathrm{T}_{4}$ At $2 \mathrm{WAP}$ were not significantly different $(\mathrm{P}<0.05)$ as they had a mean of $0.029 \mathrm{~g}, 0.045 \mathrm{~g}$ and $0.038 \mathrm{~g}$ respectively while $\mathrm{T}_{2}$ had a mean root dry weight of $0.101 \mathrm{~g}$ made it as the highest mean root dry weight at $2 \mathrm{WAP}$ and was significantly different $(\mathrm{P}<0.05)$ from other treatments. Roots grown at $4 \mathrm{WAP}$, $\mathrm{T}_{4}(0.454 \mathrm{~g})$ had the highest mean root dry weight which was significantly different $(\mathrm{P}<0.05)$ from $\mathrm{T}_{1}(0.156 \mathrm{~g})$, among the treated plots $\mathrm{T}_{3}(0.276 \mathrm{~g})$ had the lowest mean root dry weight and was significantly different $(\mathrm{P}<0.05)$ from $\mathrm{T}_{4} . \mathrm{At}$ 6WAP there was a significantly high mean root dry weight obtained in $\mathrm{T}_{3}(0.815 \mathrm{~g})$ which was significantly different $(\mathrm{P}<0.05)$ to the control $(0.166 \mathrm{~g})$ that had the lowest weight obtained. Soybean roots from plants grown in $\mathrm{T}_{4}$ had the highest mean root dry weight at $8 \mathrm{WAP}$ and $10 \mathrm{WAP}$ with a dry weight of $8.911 \mathrm{~g}$ and $13.517 \mathrm{~g}$ respectively which was significantly different $(\mathrm{P}<0.05)$ from control as shown in Table 10.

Table 10 Effect of Treatments on Root Dry Weight(g) of Soybean

\begin{tabular}{|c|c|c|c|c|c|}
\hline Treatments & 2WAP & 4WAP & 6WAP & 8WAP & 10WAP \\
\hline $\mathrm{T}^{1}-$ Control & $0.029^{b}$ & $0.156^{c}$ & $0.166^{\mathrm{d}}$ & $2.609^{c}$ & $3.865^{c}$ \\
\hline $\mathrm{T}^{2}$ & $0.101^{\mathrm{a}}$ & $0.391^{\mathrm{ab}}$ & $0.375^{c}$ & 7.587ab & $9.982^{b}$ \\
\hline $\mathrm{T}^{3}$ & $0.045^{b}$ & $0.276 b^{c}$ & $0.815^{a}$ & $5.766^{b}$ & $11.327^{\mathrm{ab}}$ \\
\hline $\mathrm{T}^{4}$ & $0.038^{b}$ & $0.454^{\mathrm{a}}$ & $0.479^{b}$ & $8.911^{\mathrm{a}}$ & $13.517^{\mathrm{a}}$ \\
\hline
\end{tabular}

\subsection{Effect of Treatment on Yield and Yield Components of Soybean}

The result in Fig. 1 revealed that number of pods was significantly influenced by treatments levels. T4 produced significantly $(\mathrm{P}<0.05)$ higher numbers of pods $(129.75)$ than the control plot $(52.75)$, this was followed by $\mathrm{T}_{3}$, that produced (74.50) pods which was higher than $\mathrm{T}_{2}$ that produced 70.00 pods as shown in Fig. 1. Mean weight showed 
that $\mathrm{T}_{1}, \mathrm{~T}_{2}$ and $\mathrm{T}_{3}$ were not significantly different $(\mathrm{P}<0.05)$ as they produced pods that weighed $12.20 \mathrm{~g}, 12.65 \mathrm{~g}$ and $13.88 \mathrm{~g}$ respectively and they were statistically different from the highest seed pod weight $\left(25.38 \mathrm{~g}\right.$ ) produced in $\mathrm{T}_{4}$ plots.

However, the 100 seed weight was not significantly different among treatments but $\mathrm{T}_{4}$ had the highest weight as $7.23 \mathrm{~g}$ while $\mathrm{T}_{3}$ obtained the lowest 100 seed weight of $6.23 \mathrm{~g}$. Similarly, the yield result showed that $\mathrm{T}_{4}$ gave the highest yield of $0.72 \mathrm{~kg} / \mathrm{ha}$ which was not significantly different $(\mathrm{P}<0.05)$ from other treatments, but $\mathrm{T}_{3}$ having the lowest yield as $0.62 \mathrm{~kg} / \mathrm{ha}$ which was not significantly different $(\mathrm{P}<0.05)$ from other treatments.

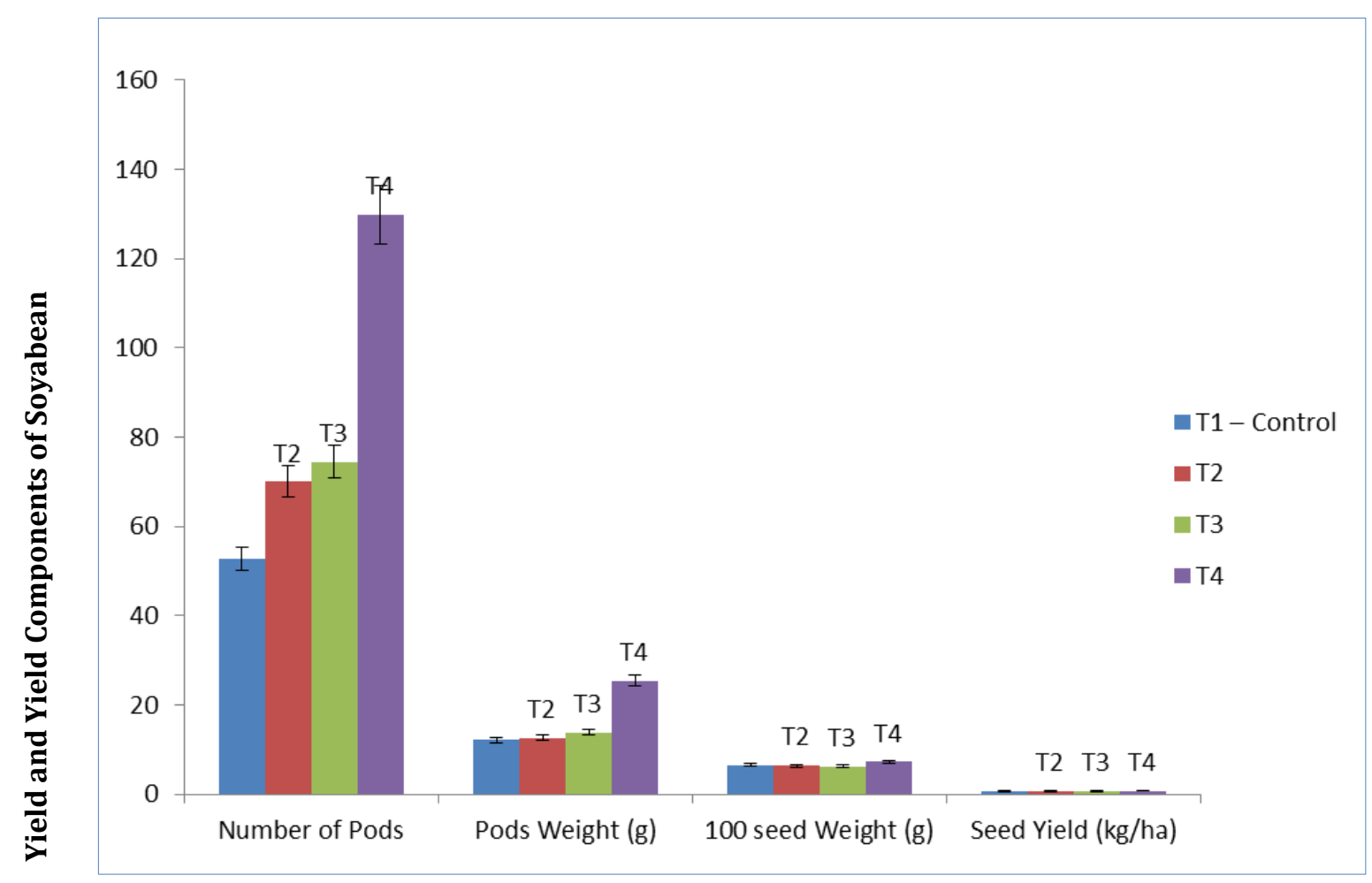

Figure 1 Effect of treatment on yield and yields components

\section{Discussion}

The study of water hyacinth as an organic manure revealed that the incorporation of water hyacinth into the soil increased the performance of the Soybean crop Morpho-Physiological parameters compare to control.

The results obtained in the study showed that application of water hyacinth compost manure increased plant height, number of leaves, compared to control. This could be as result of the release of considerable amount of potassium, phosphorus and nitrogen for plant use during the process of mineralization which leads to increase in photosynthesis of the plant. This agrees with the findings of [27],[20]. The application of organic fertilizer greatly enhanced growth, development and yield performance in terms of plant height, leaf number, leaf area and fresh weight [28] .The variation obtained in plant height and number of leafs among treatments could be due to variation in the rate of composted water hyacinth applied. This conforms with the findings of [20] who reported that a general increase in vegetative growth and yield was obtained when manures are applied to plants.

Improved leaf area, and leaf area index observed in the treated plots could be due to the rapid conversion of nitrogen content of leaves to protein leading to a larger leaf area of the soybean plant as compared to the control this is in agreement with the work of [29].

The higher shoot dry weight recorded for Soybean plant grown on the treated plots compared to the control could be attributed to the availability of Nitrogen and Phosphorus in the water hyacinth manure that were releases slowly as it decomposes. This is in support with the work of [30], where he said the higher shoot dry weight recorded for maize plants grown on soil amended with water hyacinth could be attributed to the availability of $\mathrm{N}$ and $\mathrm{P}$. This is also in support of findings of [19], who reported that compost and poultry manure significantly increased growth of fresh and dry weight of shoot and root yield of tomato compare to control. 
Net assimilation rate was greatly improved by Water Hyacinth Compost manure this improvement could be due to increase nitrogen readily available. Compost contains high amounts of organic matter which could have increased the moisture retention of soil, improved dissolution of nutrients particularly phosphorus and soil structure hence better root growth and nutrient uptake [31], it was also assumed that the phosphorus contained in the water hyacinth that probably enhanced root dry weight, number of roots and length of root, compared to the control observed in this study.

The use of water hyacinth manure gave a significant yield but equally produced an insignificant grain yield with this result it can be said that, the performance on yield of the Soybean plant may be probably due to the increase of Nitrogen availability released from the water hyacinth during the process of mineralization. The significant increase in the yield and yield components recorded in this study is in line with findings of [22], who reported that water hyacinth as biomanure incorporated in the soil crop system increased the yield and yield quality of potato tube, water hyacinth as a source of organic material is capable of improving the physical structure of the soil, increasing the availability of nutrients, vegetative growth and the production of sweet corn [20]. J.While the use of liquid organic fertilizer from seaweed had a role in the growth of soybean plants because seaweed contains a growth hormone which was needed by plants [32].

[33] in their work, said that using composted water hyacinth material could serve as quality manure for improving soil fertility condition and thus crop yield on the whole. Enhanced effects of water hyacinth have also been reported by [21]. The study of water hyacinth as a biofertilizer revealed that the incorporation of water hyacinth into soil crop system increased the performance on yield of the crop plant (Coriandrum sativum [21]. This result is also in-line with [34] who mentioned that quality and quantity of added organic materials into soil may influence the decomposition rate and mineralization process.

\section{Conclusion}

In conclusion, the results of the study indicated that water hyacinth manure can increase shoot and root growth parameters of soybean. It is recommended to be used as organic manure to improve soil fertility level of area of production and growth of soybean, $200 \mathrm{~g}\left(\mathrm{~T}_{4}\right)$ of water hyacinth compost gave the highest results in almost all the parameters measured except in plant height, and root lengths.

\section{Compliance with ethical standards}

\section{Acknowledgments}

The authors are grateful to Prof.M.O Onuh and Prof.N.C Ohazurike for their encouragement and guidance. We are also thankful for staff of Teaching and research farm of faculty of Agriculture, Imo State University.

\section{Disclosure of conflict of interest}

The authors declared that there are no conflicts of interest that may arise as result of this study.

\section{References}

[1] Arora N, Maini P. Anaerobic digested slurry -an input for sustainable agriculture, Asian Journal of Experimental Science. 2011; 25(1): 59- 6259.

[2] Norrell P, Bennett AE. How can we exploit above below ground interactions to assist in addressing the challenges of food security?" Fronterier Plant Science. 2013

[3] Arif M, Jalal F, Jan MT, Muhammad D. Integration of biochar and legumes in summer gap for enhancing productivity of cereal based cropping system, Sarhad Journal of Agriculture. 2014; 30(4): 393-403.

[4] Agunbiade FO, OluOwolabi BI, Adebowale KO. Phytoremediation potential of Eichornia crassipes in metal contaminated coastal water. Bioresource Technology. 2009; 100: 4521-4526.

[5] Robles W, Madsen JD,Wersal RM. Estimating the biomass of water hyacinth (Eichhornia crassipes (Mart.) Solms) using the normalized difference vegetation index derived from simulated lands at 5TM. Invasive Plant Science and Management. 2015; 8(2): 203-211. 
[6] Bhattacharya A, Haldar S, Chatterjee PK. Geographical distribution and physiology of water hyacinth (Eichhornia crassipses)-the invasive hydrophyte and a biomass for producing xylitol. International Journal of Chemical Technology Research. 2015; 7(4): 1849-1861.

[7] Malik A. Environmental challenge vis a vis opportunity: the case of water hyacinth. Environment international. 2007; 33(1): 122-138.

[8] Villamagna AM,Murphy BR. Ecological and Socio-Economic impacts of invasive water hyacinth (Eichlorinia Crassipes): a review, freshwater biology. 2009; 55(2): 282-298.

[9] Alvarado S, Guédez M, Lué-Merú MP, Nelson G, Alvaro A, Jesús AC, Záray G. Arsenic removal from waters by bioremediation with the aquatic plants water hyacinth (Eichhornia crassipes) and Lesser Duckweed (Lemna minor). Bioresource Technology. 2008; 99: 8436-8440.

[10] Mishra VK, Tripathi BD. Accumulation of chromium and zinc from aqueous solutions using water hyacinth (Eichlornia Crassipes). Journal Hazard Mater. 2009; 164: 1059-1063.

[11] SO LM, Chu LM,Wong PK. microbial enhancement of $\mathrm{Cu}^{2+}$ removal capacity of Eichhornia Crassipes (Mart.). Chemosphere. 2003; 52: 1499-1503.

[12] Jayaweera MW, Kasturiarachchi JC, Kularatne RKA, Wijeyekoon SLJ. Contribution of water hyacinth (Eichhornia crassipes (Mart.) Solms) grown under different nutrient conditions to fe-removal mechanisms in constructed wetlands. Journal of Environmental Management. 2008; 87: 450-460.

[13] Hadad HR, Maine MA, Mufarrege MM, Del Sastre MV, Di Luca GA. Bioaccumulation kinetics and toxic effects of Cr, $\mathrm{Ni}$ and Zn on Eichhornia crassipes. Journal Hazard Mater. 2011; 190: 1016-1022.

[14] Lu X, Kruatrachue M, Pokethitiyook P, Homyok K. Removal of cadmium and zinc by water hyacinth Eichhornia crassipes. Science Asia. 2004; 30: 93-103.

[15] Bais SS, Lawrence K, Nigam V. Analysis of heavy metals removal by Eichhornia crassipes (Mart.) Solms. World Journal of Pharmacy and Pharmaceutical Sciences. 2015; 4(9): 665-672.

[16] Zimmels Y, Kirzhner F,Malkovskaya A. Application of Eichhornia Crassipes and pistia Stratiotes for treatment of Urban Sewage in Israel. Journal of Environmental Management. 2006; 81: 420 - 428.

[17] Xia H, Ma X. Phytomediation of Ethion by water hyacinth (Eichharnia Crassipes) from water, Bioresources Technology. 2006; 97: 1050-1054.

[18] Perez EA, Tellez TR, Maqueda SR, Linares PJC, Padro FMV, Medina PLR, Moreno JL, Cortes GJ, Guzman JMS. Seed germination and risks of using the invasive plant Eichhornia Crassipes (Mart.). solms- Laub (water hyacinth) for composting, ovine feeding and biogas production. Acta Botanical Gallica. 2015; 162(3): 203-214.

[19] Mehdizadeh M, Darbandi EI, Naseri-Rad H, Tobeh A. Growth and yield of tomato as influenced by different organic fertilizers", International Journal of Agronomy and Plant Production. 2013; 4(4): 734-738.

[20] Abu Talkah. Effect of Organic Fertilizer Water Hyacinth on the Growth and Production Plant Taro (Colocasia esculenta L.) Journal of Environment and Earth Science. 2015; 5(22): 70-74.

[21] Lata N, Veenapani Dubey. The impact of water hyacinth manure on growth attributes and yields in Coriandrum sativum Journal Of Environmental Science, Toxicology And Food Technology. 2013; 5(3): 04-07.

[22] Aftab Alam, Sunit Kr. Srivastava, Kumar Anand, Pritam Bala Sinha, Prashant Kr. Mishra. Response of Water Hyacinth as a Source of Potassium in the Production of Potato. International Journal of Innovative Research inScience, Engineering and Technology.2017; 6(7): 15010-15014.

[23] Brandy NC,RR Weit. The Nature and Properties of soil $13^{\text {th }}$ Edition. New Jessey Prenilice Hall. ISBN 0.13 - 106760.2020 .

[24] Robert G, Shatter JR,Robert KV. Characterizing the interaction between fire ants (Hymenoptera: formicidae) and developing soybean Plant. J. Econ. Entomol. 2000; 93(6): 1680-1687.

[25] Barrios S, Bertinelli L, Strobl E. Climatic Change and Rural-Urban Migration: The Case of Sub-Saharan Africa. J. Urban Econ. 2006; 60(3): 357-371.

[26] Nigeria Metrological Agency (NIMET).Seasonal prediction and socio-economic implications for Nigeria.2012

[27] Sanni KO, Adesina JM. Response of water hyacinth manure on growth attributes and yield of Celosia argentea L. (Lagos spinach). Journal of Agricultural Technology. 2012. 8(3): 1109-1118. 
[28] Mojeremane, W., Motladi, M., Mathowa, T., and Legwaila, G. M.(2015), "Effect of Different Application Rates of Organic Fertilizer on Growth,Development and Yield of Rape (Brassica napus L.)", International Journal of Innovative Research in Science, Engineering and Technology,4(12): 11680-11688.

[29] Fanuel Kawaka, Mathews Dida, Peter Opala, Omwoyo Ombori, John Maingi, Alice Amoding ,John Muoma .Effect of nitrogen sources on the yield of common bean (Phaseolus vulgaris) in western Kenya, Journal of Plant Nutrition,2018. DOI: 10.1080/01904167.2018.1458870

[30] Osoro Newton, John O. Muoma, Alice Amoding, Dative Mukaminega , Morris Muthini, Omwoyo Ombori and John M. Maingi. Effects of Water Hyacinth (Eichhornia crassipes [mart.] solms) Compost on Growth and Yield Parameters of Maize (Zea mays L.). British Journal of Applied Science \& Technology .2014. 4(4): 617-633, 2014

[31] Olupot G, Etiang J, Ssali H, Nahasirye M. Sorghum yield response to Kraal manure combined with mineral fertilizers in Eastern Uganda. Muarik Bulletin. 2004; 7: 30-37.

[32] Wakifatul Hisani, Kaimuddin, and Syamsuddin Garantjang. Increasing the Production of Soybean (Glycine Max L.) By Using Mulch of Rice Straw and Applying Poc. (Liquid Organic Fertilizer) From Seaweed (Gracilaria Sp.) and Cattle's Urine. Journal of Biology, Agriculture and Healthcare. 2015;5(14): 1-8.

[33] Gunnarsson CC, Petersen CM. water hyacinths as a resource in agriculture and energy production: A literature review. Waste Management. 2007; 27: 117-129.

[34] Contantinides,M J. H. Fownes, Nitrogen mineralization from leaves and litter of tropical plants: Relationship to nitrogen, lignin and soluble polyphenol concentrations, Soil. Biol. Biochem., 1994(26) 49-55 